\title{
研究者ネット：被桨地神戸（摂津）の神社
}

\section{藤田 正*}

阪神・淡路大震災後の被災状況と三年後の復興状況 について神戸史学会がまとめている(『歴史と神戸』第 37 巻第 2 号特集神戸の被災史跡と文化財)。その二 年後の夏、なんとも落ち着かない、イライラした気分 に陥り、私は被災地の神社・二百社ほどを歩いてまわ った。被災地のコミュニティ復活の手掛かりが得られ ればの願いを込めて…というのも地震後再興された 祭りに心がときめいたからである。

\section{1. 被災後五年}

地震動への驚きに始まり、怒り、悲しみ、喜びなど の情緒を経て「萎え…諦め」に至った。が、「諦めるこ とに飽きる」ことが起り、私の内にエネルギーが潜むこ とを知った。その後、被災直後からの心理的推移をま とめ(藤田 1996)、ボランティア、神戸市復興愁話会な どの活動に参加した。一応の立ち直りである。この五 年はどの間は「神戸にいくとホッ」とし、神戸との間 に確かな「感情的一体感」を感じた。それが私の行動 の源であった。この感情的一体感は被災体験の共有か ら生まれた。それゆえに外部の人の適切なコメントに も「体験しないと地震は分からない」とまずは反発し、 他方、震災を被災者同志一誩語り合うとその人は仲間 となった。ここにあるのは被災体験の有無を基準とす るウチ・ソトの分離である。共感しあい、触れ合い、 体感しあい、独りではないことをリアルに確認できる 他者・グループが大切となった。ここで生じるグルー プ・ダイナミックスが感情的一体感を生み、被災者の 立ち直りの基盤となった。が、この関倸はリアルで、 対面的であるが故に、常に別れを伴う。私自身も地震 後五年間で尊敬していたボランティア関係の三人を病 気、事故、不注意で亡くした。死ではない別れを含め ればたくさんの人と別れた。その度に「もっと話をし ておけばよかった」といった悔いの念が起り、まるで 歯の治療直後のような噌み合わせの悪い、イライラし た気分になる。それが今の気分である。

* Masaru FUjITA

府立大阪女子大学人文社会学部人間関係学科
さて、地震はソトからの非日常的な圧倒的な力で私 たちを破壊しようとした。それに対して「個人として の私」はリアルな仲間と日常性の回復をすることで対 抗した。が、その仲間との別れが日常的に起る。する と「当の相手のいない一体感」だけが残る。喪った人 が大事な人であるほど、私の個人性は私のウチから解 体されていく。残った一体感を思い出に昇華できれば と願う。氷が水蒸気に昇華する時、水の分子は激しく 動くという。「動くこと」に集中する。これが神社を「歩 いて回った」理由である。動く中で地震後五年間の感 情的一体感が「地震という自然」と「体験を共有する 他者」いってみれば外部からの脅威と感情的一体感を 受身的に受け取ることから生じていたことに気付く。 これは私自身の受動的構えである。以前社会心理学実 験で、緊張と緊張解消の二つの過程が共存する状況で 構えが変化することを明らかにした(藤田 1975)。この 実験に要したのは精々一時間だが、地震動が緊張喚起 し、体験共有が緊張解消を実現したと考えれば年単位 で受動的構えが変化し始めたことになる。が、どこに 向かって変化しているのかが分からない。これがイラ イラの理由である。

「変化が起る。何か新しい枠組みが生まれる」と指 摘するだけでは不十分である。少なくとも「改変すべ き古い枠組みの構造と新なな枠組みが志向する方向」 が示され、それを実現するためのマネジメント過程が 提起されなければならない。我々は受動的構之・感情 ではない、能動的構え・情動にもとづく新たな枠組み を求める。ではどのような設計図を企画しうるのか。 私が考えたいのは使い捨て型消費社会ではない循環型 社会である。そのマネジメント過程については省略す るが、循環は使用したモノを使い捨てせずに新なな価 值を見出だし利用することで成立する。被災者が形成 した感情的一体感は「隣はなにをする人ぞ」式の従来 の都市生活では「古い」として廃棄されてきたことで ある。が、これを使い捨て、廃棄されるコトを被災者 は望んでいない。とはいえ、この感情的一体感のみを 追及し、二者関係での応報性を求めれば、ウチ・ソト の境界が鮮明な、いわゆるムラのコミュニティの実現 
をマチに想定することになる。いうまでもなく被災 地・神戸(捸津)はムうではなくマチだから、それは不 可能である。つまり、この感情的一体感を剩余価值と してとらえなおし、新ななマチづくりのための情動的 協動性を支える基盤に変えることこそが肝心である。 このコトが都市型災害への教訓を成立させる。

\section{2. 神戸(抒津)の神社}

情動的協動性は感情的一体感という過去を踏まえな がら未来を志向する。このことの大切さを現在的日常 性を越えた被災生活が教えた。そしてまた、前世、来 世の言葉が示すように宗教が現在をはみ出す時を提起 している。それゆえに余震の恐怖におびえながら「神 様、悪かった、もう勘弁して!」と祈った。この生活と 宗教の重なりは天神さまへの合格祈願が代表的だが 我々が行う行動に潜んでおり、時折姿を見せる。が、 未来は現時点での事実ではない。故に物語によってし か語ることは出来ない。また過去の事実を全て言い尽 くすことは困難である。ある目的に従って生起した出 来事の幾つかを選んで物語化するしかない。古事記・ 日本書紀はこのような物語であり、そこには多くの 神々が登場し、今も神社にいるとされる。神話空間に はこのような過去・現在・未来の混然一体性がある。 実は被災者もこの混然一体性を体験した。例えば、 「(PTSDの)こころのケア」で有名になったフラッシ ュバックだが、日常生活が可能になった後の悲㥄な震 災場面のフラッシュバックだけではなく、余震の恐怖 に怯える中で地震前の安全な神戸の風景もまたフラッ シュバックされた。この混然一体性を物語化すること で未来の神戸を見ようとした。䛊解されては困るが私 は神話が史実だといっているのではない。そこでの「混 然一体性からの物語化の仕組み」が参考になるのでは ないかということを主張しているのである。これが神 社に注目しな理由である。

神社の配置。これが検討の手始めである。まず寺院 との比較で神戸(捸津)がマチ的であることを確認する。 ごく素朴に寺院と神社の数を都道府県ごとに見ると、 いわゆるマチ的地域 (大阪、京都、滋賀、東京など) と 思われる所で寺院が多く、反对にムラ的な所(新潟、福 島、高知など)には神社が多い。兵庫県には神社も寺院 も共に多いのだが、兵庫県を構成する旧国領でみると 摄津は播磨、淡路、丹波、但馬と異なり神社が多い。 神戸市でみると神戸西方・旧播磨の垂水区・西区では 神社が多く、最も大きな被害があった阪神間のいわば 六甲山脈南側の海岸沿いの搨津地域では寺院が多い
（但し、山田村、住吉村と異称される北区・東灘区では 神社・寺院はほほ同数である)。つまり、激災地・掑津 の地域特性はほぼマチ的といえる。さらに、穀神を祭 神とする大藏 (年) 神社は掑津には殆どないが、掑津の 西と北の地域には数多い。このことも神戸(搨津)を田 を中心とするムラ地域とは考えられないことを示して いる。神戸(捸津)で見たマチの神社の特徵とは何だろ うか。神社の境内には杜があり、そこで子供たちが遊 んでいる。これが四国出身の私が抱く神社イメージで ある。しかし、生田神社が代表的だが摂津地区にある 多くの神社境内は駐車場になっている。正值、違和感 を感じた。ではここは神社ではないのか。車から降り た人が慣れた様子で神殿に軽く頭を下げている。その 時気付いた。彼等がマチの神社の氏子なのだと。震災 後地元の人々によって復旧された境内に一本の木もな い神社さえある。私のムラ的神社イメージを変える必 要がある。マチのコミュニティ、これが現在の私の課 題だが、マチは移動する人々によって形成される。人々 は無方向に移動するのだろうか。旧生田神社と兵庫生 田神社を結ぶとその直線上に生田神社裔神を祭る四宮 神社と六宮神社がある。東から西に保久良、弓弦羽、 綱敷天満、徳井、敏馬、三宮、走水、八宮、証誠など の神社がほぼ直線上に並ぶ。また、本住吉神社を中心 にした円周上に徳井、東明、魚崎、山王、猿田彦など の神社がある。さらには四宮神社が中心の同心円があ ク、内円には五宮、八宮、三宮、現生田など生田神社 関連の神社、外円には荒田、北野、小野の神社がのる。 他にもこのような直線、冈周がいくつもある。これら の直線、冈周が持つ個々の神道的意味は私には分から ないが、明らかにドゥールズ・ガ夕リのいう条里空間 であることは間違いない。

復興を日指して新ななマチの空間を作り出そうとす る時、丁度地震後の瓦喽のようにこれらの神社が示し てきな条里空間を捨て去ってよいのだろうか。私はそ うは思わない。検討すべき重要な神戸・掑津の設計モ デルとして活かすことが出来るのではないな゙ろうか。 但しその際に、ドゥールズらのいう遊牧空間、多孔空 間の機能を検討する必要がある。というのは、条里空 間のダイナミックスはこれらの笁間との関わりで生ま れているのだから。

[問い合わせ先]

干 590-0035 堺市大仙町 2-1

府立大阪女子大学人文社会学部人間関係学科

藤田 正

TEL : 0722-22-4811

FAX : 0722-22-4791 